\title{
GAYA CINTA (LOVE STYLE) MAHASISWA
}

\author{
Risky Ananda Ariyati, \\ Fathul Lubabin Nuqul, \\ email:lubabin_nuqul@uin-malang.ac.id
}

Fakultas Psikologi

Universitas Islam Negeri (UIN) Maulana Malik Ibrahim Malang

Jl. Gajayana 50 Malang Telp.0341-558916

\begin{abstract}
Abstrak- Cinta adalah salah satu bentuk emosi yang mengandung ketertarikan, hasrat seksual, dan perhatian pada seseorang. Cara seseorang mencintai dan mengekspresikan rasa cintanya berbeda-beda, yang kemudian disebut dengan gaya cinta. Ada 6 gaya cinta yaitu eros (cinta romantis), ludos (cinta main-main), strong (cinta persahabatan), mania (cinta posesif), pragma (cinta realistis), agape (cinta tanpa pamrih). Tujuan penelitian ini untuk mengetahui gaya cinta (love style) mahasiswa ditinjau dari jenis kelamin. Penelitian ini melibatkan 190 subjek yang merupakan mahasiswa. Instrumen yang digunakan adalah adaptasi dari skala Love Attitude Scale (LAS). Hasil penelitian ini menunjukkan bahwa subjek berkecenderungan mempunyai gaya cinta yang kombinatif 120 responden atau $63,2 \%$. Penelitian ini juga menemukan bahwa laki-laki lebih memiliki gaya cinta ludos (cinta main-main) dan agape (cinta tanpa pamrih) dibandingkan perempuan.
\end{abstract}

PSIKOISLAMIKA. Jurnal Psikologi Islam (JPI) copyright @ 2016 Pusat Penelitan dan Layanan Psikologi. Volume 13 Nomor 2 Tahun 2016

\section{PENDAHULUAN}

Cinta akan selalu menjadi topik yang digandrungi oleh setiap kalangan, baik yang muda maupun yang tua, terbukti dari lirik lagu, drama, teater, puisi, sajak, komik, novel, bahkan gosip tentang cinta (Wisnuwardhani, 2012). Bahkan sekarang cinta menjadi topik populer pada riset ilmiah (Taylor, 2009).

Menurut Antonucci, salah satu kelompok yang tidak lepas dari masalah cinta adalah individu yang berada pada tahap perkembangan dewasa awal (Irmawati dan Saragih, 2005). Kehidupan psikososial dewasa awal semakin kompleks dibandingkan masa remaja khusunya yang memilih untuk melanjutkan jenjang ke perguruan tinggi. Pemilihan dan menemukan calon pasangan hidup adalah salah satu tugas perkembangan pada dewasa awal. Pemilihan akan menikah ataupun hanya sekedar hubungan pranikah atau biasanya disebut pacaran atau yang lainnya adalah wajar bagi dewasa awal karena mengingat tugas perkembangan tersebut (Hurlock, 1980).
Individu pada masa dewasa awal, perempuan maupun laki-laki, selain mencoba berbagai pekerjaan sebelum menentukan pilihan juga cenderung bergonta-ganti pasangan sebelum menentukan pasangan hidup yang dirasanya cocok. (Hurlock, 1980). Relasi hubungan cinta inilah yang menjadikan kegagalan dalam hubungan cinta tidak terjadi pada masa pernikahan saja, akan tetapi hubungan pranikah akan mengalami lebih besar kegagalan cinta sebelum menentukan pasangan yang sesuai.

$\mathrm{Hal}$ tersebut terkait dengan kenyataan yang terjadi di masyarakat, kasus tentang hubungan cinta terjadi mulai dari kekerasan hingga kasus pembunuhan. Kebanyakan kekerasan terjadi karena adanya keinginan untuk selalu ingin tau tentang pasangannya dan membatasi setiap ruang gerak pasangan karena rasa takut kehilangan atau rasa memiliki yang terlalu tinggi, biasanya orang akan menyebutnya sebagai pasangan yang posesif (mania). Sedangkan orang yang menjadi korban adalah orang yang mempunyai prinsip rela melakukan apapun demi pasangnnya atau dalam teori gaya cinta lebih dikenal sebagai Altruistik (agape). Kondisi 
ini akan terus berlangsung karena korban merasa harus berkorban demi kebahagiaan pasangan yang dicintai, dan tidak akan melaporkan kekerasan yang diterimanya. Kedua tipe cinta tersebut sangat menguras emosi, bahkan cenderung penuh tekanan (Harian Umum Pelita, 2012).

Cinta yang seharusnya berlandaskan dengan kasih sayang, kepedulian, dan kebahagiaan ternyata memiliki beberapa gaya yang sangat menguras emosi dan bahkan cenderung penuh tekanan yaitu dari beberapa kasus yang dikemukakan ditemukan adanya beberapa gaya cinta yaitu gaya cinta altruistik (agape) dan posesif (mania), John Lee (Taylor, 2009) mengemukakan masih ada empat gaya cinta lain yang akan ditunjukkan pada setiap individu, yaitu gaya cinta kawan baik (stonge), main-main (ludos), pragmatic (pragma) dan romantik (eros). Dalam keenam gaya cinta tersebut mempunyai kelebihan dan kekurangan, biasanya individu cenderung memiliki dua sampai tiga jenis dari gaya cinta tersebut dalam sebuah relasi yang dijalin mereka. Selain itu gaya cinta yang positif adalah gaya cinta yang menyenangkan dan terjalin dalam suasana yang hangat, biasanya ada dalam bentuk gaya cinta kawan baik (stronge), juga altruistik (agape) yang merupakan kombinasi dari eros dan storge. Sementara untuk keempat gaya cinta tersebut lebih menguras tenaga dan bisa membawa dampak negatif (Taylor, 2009).

Hendrick dan Hendrick (1986) meneliti gaya cinta dan seksualitas memiliki hubungan yang signifikan dengan dengan jenis kelamin, etnis, pengalaman cinta sebelumnya, status, dan harga diri. Hasil penelitian itu didukung oleh penelitian Cannary tentang hubungan antara peran gender dan pengertian tentang cinta. Secara khusus, cinta sebagai permainan (ludus) lebih mengarah pada maskulinitas dan jarang berhubungan dengan feminitas. Jenis cinta posesif atau tergantung (mania) cenderung berkaitan dengan feminitas dan jarang ada pada sifat maskulinitas. Perempuan lebih pragmatis (pragma) dibandingkan laki-laki. Perempuan memiliki gagasan yang realistis dari cinta (Cannary, 1997). Kesimpulan dalam penelitian ini, maskulinitas tidak berhubungan dengan sikap eros (romantis), storge (persahabatan atau companionate), agape (self-less; cinta tanpa pamrih), juga pragma (pragmatis). Sementara itu feminitas terkait dengan semua enam jenis cinta (Cannary, 1997)

Perbedaan gaya cinta dari penelitian sebelumnya inilah yang cukup sulit untuk menggolongkan seseorang berada dalam gaya cinta seperti apa, dari enam gaya cinta yang ada. Akan tetapi, bisa dikatakan bawasannya perempuan cenderung memaknai cinta dalam suatu hubungan dengan kedekatan emosional, atau cinta yang mengutamakan keakraban yang menyenangkan yaitu pada gaya cinta stronge (cinta persahabatan), pragma (cinta realistis), mania (cinta obsesif), dan agape (cinta tanpa pamrih) sementara laki-laki cenderung menggunakan kedekatan gaya cinta yang berasal dari dari fisik jasmaniah yaitu pada gaya cinta eros (cinta romantis), dan ludos (cinta permaianan). Seperti hasil riset juga menunjukkan ada perbedaan seks dalam gaya percintaan, laki-laki lebih cenderung pada gaya bercinta romantik, main-main atau egosentric, sementara perempuan cenderung pada gaya cinta persahabatan, obsesive atau inscure atau pragmatik (Dayakisni \& Hurdaniah, 2009).

Oleh karena itu, peneliti tertarik lebih lanjut meneliti mengenai perbedaan gaya cinta mahasiswa ditinjau dari jenis kelamin, karena sebelumnya peneliti hanya menemukan kecenderungan gaya tanpa mengetahui perbedaan yang ada pada jenis kelamin itu sendiri. Fokus penelitian ini bukan hanya mahasiswa yang merasa dirinya berpacaran, akan tetapi penelitian ini akan mengambil beberapa subjek yang merasa dirinya memiliki hubungan (relation) cinta yang terjalin dengan lawan jenisnya baik itu resmi maupun tidak. Penelitian ini mengambil subjek mahasiswa dari Universitas Islam Negeri Maulana Malik Ibrahim Malang, sehingga tujuan dalam penelitian ini adalah mengetahui gaya cinta yang ada serta perbedaan gaya cinta mahasiswa ditinjau dari jenis kelamin di Universitas Islam Negeri Maulana Malik Ibrahim Malang (UIN Malang).

\section{METODE}

\section{Subjek}

Sampel dari penelitian ini berjumlah 190 orang dengan rincian 81 laki-laki dan 109 perempuan. Subyek merupakan mahasiswa S1 di Universitas Islam Negeri Maulana Malik Ibrahim Malang. Subjek dipilih yang memiliki hubungan cinta (pacaran, pernikahan dan lain sebagainya).

Teknik Pengumpulan Data

Metode pengumpulan data dengan adaptasi skala love attitude scale (Hendrick \& Hendrick, 1986) yang teradaptasi untuk mengukur gaya cinta mahasiswa. Skala ini berjumlah 24 aitem. Skala love attitude scale disusun berdasarkan aspek gaya cinta yaitu: Cinta romantic (eros), $\alpha=0,632$ contoh pernyataannya "Saya dan pasangan saya 
memiliki chemistry diantara kami"; Cinta main-main (ludos), $\alpha=0,813$. "Saya memiliki lebih dari satu pasangan";. Cinta kawan baik (stronge), $\alpha=0,542$ contoh pernyataannya "Cinta adalah persahabatan yang mendalam, tidak emosional, misterius dan mistik"; Cinta posesif (mania), $\alpha=0,560$. contoh pernyataannya "Saya curiga bila pasangan saya tidak mengangkat telpon"; Cinta prakmatis (pragma), a $=0,709$ contoh pernyataannya "Saya dan pasangan saya harus memiliki agama yang sama": Cinta tanpa pamrih (agape). $\alpha=0,676$ contoh pernyataannya "Saya lebih suka menderita dibanding jika pasangan saya yang menderita" Selain dengan skala, subyek juga diberi angket untuk mengungkap diri tentang demografi, locus daya tarik pada pasangan serta tujuan dalam menjalin hubungan romantis

\section{HASIL DAN DISKUSI}

Penelitian survei ini menemukan adanya perpaduan (kombinasi) gaya cinta yang paling tinggi yaitu berjumlah 120 responden atau $63,2 \%$, terdapat lebih dari dua atau lebih gaya cinta yang dominan. Selain kombinasi ada gaya cinta pragma (cinta realitas) dengan jumlah 49 responden atau $25,8 \%$, dan gaya cinta ludos (cinta main-main) memiliki prosentase terendah dengan jumlah 1 responden atau $0,5 \%$.

Tabel 1: Kategorisasi Gaya Cinta Laki-laki dan Perempuan

\begin{tabular}{lcccccc}
\hline ASPEK & LAKI-LAKI & $\%$ & PEREMPUAN & $\%$ & JUMLAH & $\%$ \\
\hline Eros & 2 & $2,5 \%$ & 2 & $1,8 \%$ & 4 & $2,1 \%$ \\
\hline Ludos & 1 & $1,2 \%$ & 0 & $0 \%$ & 1 & $0,5 \%$ \\
\hline Storge & 4 & $4,9 \%$ & 3 & $2,8 \%$ & 7 & $3,6 \%$ \\
\hline Mania & 0 & $0 \%$ & 2 & $1,8 \%$ & 2 & $1,1 \%$ \\
\hline Pragma & 17 & $21 \%$ & 32 & $29,4 \%$ & 49 & $25,8 \%$ \\
\hline Agape & 4 & $4,9 \%$ & 3 & $2,7 \%$ & 7 & $3,7 \%$ \\
\hline Kombinasi & 53 & $65,5 \%$ & 67 & $61,5 \%$ & 120 & $63,2 \%$ \\
\hline TOTAL & $\mathbf{8 1}$ & $100 \%$ & 109 & $100 \%$ & 190 & $100 \%$ \\
\hline
\end{tabular}

Peneliti juga mengelompokkan kombinasikombinasi dari gaya cinta tersebut. Skor yang paling tinggi menujukkan perpaduan gaya cinta yang dominan dari ragam kombinasi lainnya. Penelitian ini juga menujukkan memiliki beberapa gaya cinta yang dominan (kombinasi) dari pada gaya cinta murni, diantaranya ragam kombinasi gaya cinta yang paling tinggi adalah storge-pragma yaitu cinta kawan baik dan cinta realistis berjumlah 25 responden. Hal ini menujukkan kombinasi dari gaya cinta storge dan pragma memiliki perpaduan yang paling tinggi daripada ragam kombinasi lainnya.

Tabel 2: Perbedaan Gaya Cinta (Love Style) Mahasiswa antara Laki-laki dan perempuan

\begin{tabular}{llccc}
\hline \multirow{2}{*}{ No } & \multicolumn{1}{c}{ Aspek } & \multicolumn{2}{c}{ Rerata } & \multirow{2}{*}{ Laki-laki } \\
& Perempuan & Status \\
\hline 1. & Cinta Romantik (Eros) & 9,06 & 9,14 & Ns \\
2. & Cinta main-main (Ludos) & 10,62 & 9,07 & Sig \\
3. & Cinta Kawan Baik (Storge) & 6,53 & 6,45 & Ns \\
4. Cinta Posesif (Mania) & 7,40 & 6,90 & Ns \\
5. Cinta Realitas (Pragma) & 16,89 & 16,89 & Ns \\
6. & Cinta tanpa pamrih (Agape) & 13.14 & 12,12 & Sig \\
\hline
\end{tabular}

Note: (Sig) ada perbedaan signifikan gaya cinta / (Ns) tidak ada perbedaan gaya cinta

Berdasarkan tabel 2 secara keseluruan aspek ludos (cinta main-main) dan agape (cinta tanpa pamrih) memiliki perbedaan. Pada aspek ludos, jenis kelamin laki-laki memiliki skor yang lebih tinggi dari pada perempuan, ini dapat dilihat dari mean laki- laki berjumlah 10,62 sedangkan perempuan 9,07. Selain itu pada aspek agape ternyata memiliki skor yang hampir sama, dimana skor laki-laki lebih tinggi dari pada perempuan yaitu untuk mean laki-laki berjumlah 13,14 sedangkan perempuan 12,12. 
Secara keseluruan aspek ludos (cinta mainmain) dan agape (cinta tanpa pamrih) memiliki perbedaan. Perbedaan yang ditunjukkan bahwa laki-laki memiliki kecenderungan yang lebih tinggi daripada perempuan. Hal ini menunjukkan bahwa laki-laki memiliki gaya cinta ludos (cinta mainmain) dan agape (cinta tanpa pamrih) yang lebih tinggi daripada perempuan, sedangkan gaya cinta eros (cinta romantik), storge (cinta kawan baik), mania (cinta posesif), dan pragma (cinta realitas) tidak memiliki perbedaan antara laki-laki dan perempuan.

Gaya cinta ludos (cinta main-main) merupakan gaya cinta yang lucu, genit dan riang, dimana pecinta ludos tidak peduli dengan komitmen dan hanya memikirkan tentang kesenangan yang sesaat. Tidak ada hubungan yang berlangsung lama dan biasanya berakhir setalah muncul kejenuhan, biasanya orang yang memiliki gaya ini disebut play boy (untuk laki-laki) dan play girls (untuk perempuan) (Taylor, 2009). Penelitian ini menemukan bawasannya lakilaki memiliki gaya cinta ludos (cinta main-main) yang lebih tinggi dari pada perempuan. Hal ini sama dengan pernyataan Dayaksini \& Hurdainah (2009) yang mengungkapkan bahwa laki-laki cenderung pada gaya bercinta romantik, mainmain atau egosentric. Selain itu hasil penelitian ini didukung oleh hasil penelitian Cannary (1997) yang menemukan tentang hubungan antara peran gender dan pengertian tentang cinta, secara khusus, cinta sebagai permainan (ludus) lebih mengarah pada maskulinitas dan jarang berhubungan dengan feminitas.

Pada tahap perkembangan dewasa awal, individu akan mengalami perubahan signifikan dalam hubungan personal dengan orang lain, terutama yang berkaitan dengan menjalin dan membangun ikatan berdasarkan pertemanan, cinta dan seksualitas (Papalia, 2008). Erikson mengungkapkan bahwa individu pada tahap perkembangan ini akan berusaha mencari dan menemukan pasangan hidup yang tepat, sebagimana berkenaan dengan tugas perkembangannya yang sangat penting, yaitu membina hubungan intim (Papalia, 2008). Erikson mengungkapkan perkembangan psikososial dewasa awal termasuk kedalam tahap intimacy versus isolation. Jika dewasa awal tidak dapat melakukan komitmen pribadi secara mendalam dengan orang lain, mereka akan terisolasi dan cenderung memisahkan diri. Erikson juga menjelaskan bahwa "virtue" dari tahapan dewasa awal adalah "love", yaitu kesetiaan antara pasangan yang telah memilik untuk berbagi kehidupan bersama. Hal ini menujukkan bahwa tugas perkembangan dewasa awal itu sendiri adalah pemilihan pasangan dan berkomitmen untuk masa depan. Penelitian ini menemukan bawasannya gaya cinta ludos (cinta main-main) pada laki-laki lebih tinggi dari pada perempuan, sehingga dapat dikatakan laki-laki akan lebih cenderung mengalami isolasi atau memisahkan diri daripada perempuan atas dasar gaya cinta ludos yang memiliki nilai prosentase laki-laki lebih tinggi daripada perempuan.

Sementara gaya cinta agape (cinta tanpa pamrih) juga memiliki perbedaan antara laki-laki dan perempuan. gaya cinta ini adalah orang yang mempunyai prinsip rela melakukan apapun demi pasangnnya, individu yang memiliki kesetiaan yang tinggi pada pasangannya dan tanpa pamrih untuk hubungan cinta (Taylor, 2009), bisa dikatakan gaya cinta ini adalah salah satu tipe gaya cinta yang menguras emosi, bahkan cenderung penuh tekanan apabila pasangannya tidak mmberikan timbal balik akan gaya ini. Penelitian ini menemukan bawasannya laki-laki memiliki gaya cinta agape (cinta tanpa pamrih) yang lebih tinggi dari pada perempuan. $\mathrm{Hal}$ ini bertolak belakang dengan hasil penelitian Dayaksini \& Hurdainah, (2009) bawasannya laki-laki lebih cenderung gaya bercinta romantik, main-main atau egosentric, sementara perempuan cenderung pada gaya cinta persahabatan, obsesive atau inscure atau pragmatik. Kecenderungan untuk mengalah kepada pasangan serta melihat pasangannya sebagai berkah dan ingin merawatnya juga kesetiaan merupakan arti dari pecinta agape.

Adapun hipotesis penelitian ini adalah terdapat perbedaan gaya cinta mahasiswa antara laki-laki dan perempuan dimana perempuan cenderung memaknai cinta dalam suatu hubungan dengan kedekatan emosional, atau cinta yang mengutamakan keakraban yang menyenangkan yaitu pada gaya cinta stronge (cinta persahabatan), pragma (cinta realistis), mania (cinta obsesif), dan agape (cinta tanpa pamrih) sementara laki-laki cenderung menggunakan kedekatan gaya cinta yang berasal dari dari fisik jasmaniah yaitu pada gaya cinta eros (cinta romantis), dan ludos (cinta permaianan). Akan tetapi hasil penelitian ini menyimpulkan bawasannya hanya ada perbedaan pada aspek ludos (cinta main-main) dan agape (cinta tanpa pamrih) antara laki-laki dan perempuan. Pada aspek eros (cinta romantik), storge (cinta kawan baik), mania (cinta posesif), dan pragma (cinta realitas) tidak ada perbedaan gaya cinta (love style) antara lakilaki dan perempuan. 
Setelah mengetahui beberapa perbedaan gaya cinta mahasiswa pada laki-laki dan perempuan. Pembahasan kali ini merujuk kepada alasanalasan orang tersebut mencintai atau menyukai. Pada kehidupan psikososial dewasa awal semakin kompleks dibandingkan masa remaja khusunya yang memilih untuk melanjutkan jenjang ke perguruan tinggi. Pemilihan dan menemukan calon pasangan hidup adalah salah satu tugas perkembangan pada dewasa awal. Pemilihan akan menikah ataupun hanya sekedar hubungan pranikah atau biasanya disebut pacaran atau yang lainnya adalah wajar bagi dewasa awal karena mengingat tugas perkembangan tersebut (Hurlock, 1980). Pemilihan pasangan pranikah maupun menikah pada seseorang memiliki kriteria masing-masing dalam menyukai maupun mencintai, Myers (2012) mengungkapkan beberapa faktor yang memunculkan menyukai dan mencintai yaitu kedekataan, fisik yang menarik, persamaanperbedaan, dan imbalan dalam hubungan.

Ketertarikan pribadi itu sendiri adalah kesukaan pada orang yang membentuk atau menimbulkan rasa suka pada seseorang, ketertarikan pribadi memliki arti bahwa seseorang mempunyai ketertarikan tersendiri kepada orang lain, pada umumnya orang menilai seseorang memiliki daya tarik atau tidak tergantung pada daya tarik pribadi yang dimilikinya. Penilaian daya tarik pribadi adalah penilaian utama sebelum memutuskan mencintai. Daya tarik pribadi terdiri dari daya tarik fisik, kepribadian, kecerdasan, prestasi, dan daya tarik sosial (Faturochman, 2006). Penelitian yang dilakukan oleh Faturochman (1988) menujukkan bahwa pada umumnya orang lebih mengukur psikis seperti nilai-nilai, kepribadian, kecerdasan, prestasi, dan keberhasilan daripada faktor yang bersifat fisik seperti ketampanan atau kecantikan dan kedekatan fisik. Pernyataan ini juga sesuai dengan hasil penelitian yang dilakukan pada mahasiswa bawasannya ketertarikan pribadi memiliki jumlah responden yang lebih tinggi daripada yang lainnya.

Daya tarik selanjutnya adalah kesamaan atau kemiripan Sarwono (2009) mengungkapkan bahwa sangat menyenangkan ketika seseorang menemukan orang yang mirip dengannya dan saling berbagi asal-usul, minat, dan pengalaman yang sama. Semakin banyak persamaan, semakin merasa saling menyukai. Seseorang cenderung menyukai orang yang mirip dalam hal sikap, nilai, latar belakang; dan personality (Taylor, 2009). Penelitian ini menemukan adanya perbedaan antara laki-laki dan perempuan untuk status pacaran dan lain-lain (pranikah), menujukkan daya tarik kesamaan pada laki-laki lebih tinggi dari pada perempuan. Sedangkan untuk yang berstatus menikah tidak ada yang masuk kedalam kategorisasi kesamaan. Akan tetapi pada penelitian ini menemukan intensitas keyakinan dengan daya tarik yang dimiliki responden, menunjukkan bawasannya laki-laki maupun perempuan cenderung tidak yakin kepada pasangannya dikarenakan daya tarik kesamaan.

Sebuah penelitian yang dilakukan oleh Gaunt (dalam Sarwono, 2009) ditemukan bawasannya pasangan suami istri yang memilki kepribadian yang hampir sama akan memiliki pernikahan yang lebih bahagia daripada pasangan suami istri yang memiliki kepribadian berbeda. Dalam hal berkencan (pranikah) dan pernikahan, tendensi untuk memilih pasangan yang mirip dinamakan matching principle (prinsip pasangan). Pasangan kencan atau pasangan suami istri cenderung mencari kesesuaian bukan hanya dalam nilai dan sikap, tetapi juga dalam penampilan fisik, latar belakang, dan personalitas. Penelitian yang dilakukan Hill \& Peplau (Taylor, 2009) misalnya, sebuah studi terhadap pasangan kencan menemukan bahwa pasangan-pasangan itu cenderung mirip satu sama laindalam hal usia, kecerdasan, cita-cita pendidikan, agama, daya tarik fisik, dan bahkan tinggi badan. Penelitian ini juga menemukan adanya daya tarik dalam hal kesamaan atau kemiripan yang terlihat dari statu pacaran dan lain-lain (pranikah), dimana laki-laki lebih memilih pasangannya atas dasar kesamaan atau kemiripan daripada perempuan. Akan tetapi jauh berbeda dengan hasil yang berstatus menikah, bawasannya tidak ada yang masuk kedalam kategorisasi kesamaan atau memiliki daya tarik yang berbeda untuk memilih pasangannya.

Kemiripan begitu penting bagi daya tarik interpersonal, Taylor (2009) mengungkapkan salah satu kemungkinannya, adalah masing-masing memiliki pandangan religius yang kuat dan menggunakannya untuk menyaring calon pasangan atau pacar. Kemungkinan lainnya adalah partner (pasangan) itu mungkin pada awalnya berbeda sikap tetapi kemudian perlahan-lahan saling membujuk satu sama lain untuk mengubah pandangan. Kemungkinan ketiga adalah hubungan itu dipengaruhi oleh faktor lingkunngan yang menyebabkan orang dengan sikap yang sama akan saling bertemu.

Akan tetapi, perbedaan juga tidak kalah menyenangkan daripada persamaan. Jones menjelaskan bahwa seseorang merasa senang saat menemukan terdapat hal yang mirip dengan orang yang disukai, 
tetapi ternyata lebih menyenangkan saat seseorang mengetahui bahwa orang yang disukai memiliki pandangan berbeda dengan yang dimiliki (Sarwono, 2009). Hal ini terjadi karena perbedaan bukan merupakan salah satu sikap yang salah akan tetapi sebalinya yaitu opini apa adanya orang tersebut tanpa adanya paksaan, selain itu perbedaan juga dapat membuat seseorang belajar hal yang baru dan bernilai darinya. Menurut Myers (2012) mengungkapkan bawasannya perbedaan membuat sikap saling melengkapi antar hubungan yang dilajin. Kemungkinan inilah yang memungkinkan ditemukan adanya ketidak yakinan pada daya tarik kesamaan laki-laki maupun perempuan.

Fisik yang menarik adalah kategorisasi daya tarik selanjutnya, dimana pada responden yang memiliki status pacaran dalam penelitian ditemukan laki-laki memiliki skor lebih tinggi daripada perempuan yaitu 14 responden atau $25 \%$ untuk laki-laki dan 6 reponden atau $7,2 \%$ untuk perempuan. Dan untuk responden yang memiliki yang memiliki status lain-lain hanya laki-laki yang masuk kedalam kategorisasi ini yakni memiliki 5 reponden atau 20,8\%. Selanjutnya untuk responden yang memiliki status menikah berjumlah 1 respoden untuk laki-laki dan 15 reponden untuk perempuan, karena laki-laki hanya 1 responden dan masuk kedalam kategorisasi lainnya. Jadi skor lainnya untuk responden perempuan pada kategorisasi ketertarikan fisik memiliki 3 responden atau $20 \%$.

Sarwono (2009) mengungkapkan bawasannya seseorang akan memilih orang yang menarik dibandingkan orang yang kurang menarik karena orang yang menarik memiliki karakteristik lebih positif. Pada penelitian Berscheid dkk (Myers, 2012) mengungkapkan bawasannya fisik yang menarik dari seorang perempuan muda merupakan suatu penanda yang cukup baik mengenai seberapa sering perempuan tersebut berkencan, dan fisik yang menarik dari seorang laki-laki muda merupakan penanda yang kurang tepat mengenai seberapa sering laki-laki tersebut berkencan. Terlebih lagi, dibadingkan para laki-laki perempuan lebih sering berkata bahwa mereka lebih memilih pasangan yang mencintai rumah dan hangat daripada seseorang yang menarik, namun dingin (Myers, 2012). Penelitian selanjutnya adalah penelitian yang dilakukan Feingold dkk (Myers, 2012) yang melakukan penelitian dengan memberikan mereka informasi mengenai seseorang lawan jenis, termasuk foto orang tersebut, kepada mahasiswa-mahasiswa laki-laki dan perempuan yang memiliki orientasi seks heteroseksual. Dalam penelitian semacam ini, laki-laki cenderung lebih banyak menilai pada daya tarik fisik lawan jenisnya daripada perempuan. Pernyataan ini hampir sama dengan hasil penelitian survei yang dilakukan pada mahasiwa UIN Malang yang berjumlah 190 responden yakni 81 laki-laki dan 109 perempuan, dimana ditemukan laki-laki memiliki skor yang lebih tinggi dalam menilai pada daya tarik fisik pada pasangannya daripada perempuan. Penilaian daya tarik fisik laki-laki yang memiliki skor yang lebih tinggi ini berlaku kepada respoden yang memiliki statu pacaran dan lain-lain yaitu hubungan yang terjalin sebelum pernikahan (pranikah).

Alasan laki-laki yang lebih memilih perempuan dari fisiknya yang memungkinan, perempuan menhalami beberapa kekhawatiran mengenai penampilannya. Dalam sebuah studi yang dilakukan Regan (Taylor, 2009) mengevaluasi perempuan yang terlalu gendut, dan ditemukan bawasannya perempuan gendut sebagai sosok yang tidak menarik secara seksual, kurang ahli, dan kurang ramah dibanding perempuan yang tubunya sedang, namun mereka tidak membedakan antara laki-laki gendut dengan laki-laki normal. Sehingga tidak heran hampir 90 persen perempuan memilih untuk bedah plastik (ASAP, dalam Myers, 2009).

Daya tarik yang terakhir adalah keakraban atau kedekatan, di mana dalam penelitian ini ditemukan bawasannya perempuan memiliki kecenderungan daya tarik lebih tinggi daripada laki-laki. Sedangkan untuk yang memiliki status lain-lain laki-laki memiliki kecenderungan yang lebih tinggi dari pada perempuan, serta untuk status menikah hanya perempuan saja yang masuk kedalam kategorisasi ini. Selain itu, penelitian ini juga menemukan perempuan memiliki intensitas keyakinan yang tinggi daripada laki-laki. Hal ini menujukkan bawasannya perempuan lebih yakin kepada pasangannya dengan ketertarikan keakraban atau kedekatan daripada laki-laki.

Kedekatan secara geografis: jarak fungsional, secara kuat memprediksi rasa suka (Myers, 2012). Orang yang secara fisik dekat biasanya lebih mudah ditemui ketimbang orang yang jauh. Jadi tidak heran jika orang biasanya tidak menyukai atau menjadi teman dari seseorang yang belum pernah ditemuinya (Taylor, 2009). Para psikolog evolusi berpendapat bahwa manusia mungkin punya ketakutan bawaan terhadap hal-hal yang asing, sebab orang dan objek yang asing atau tak dikenal mungkin merupakan ancaman, sebaliknya orang dan sesuatu yang sudah diakrabi atau dikenal baik mungkin menimbulkan 
perasaan nyaman. Oleh sebab itu keakraban atau familiaritas dapat menambah rasa suka (Taylor, 2009). Bossard dkk (dalam Myers, 2012) juga menambahkan bahwa kebanyakan orang menikahi orang-orang yang tinggal dalam lingkungan yang sama. Hal ini yang menunjukan responden yang masuk kedalam kategorisasi keakraban atau kedekatan adalah responden yang memilih pasangannya yang tidak jauh dari lingkungannya atau sering dilihat responden.

Setelah mengetahui perbedaan gaya cinta serta daya tarik antara laki-laki dan perempuan, diketahui jumlah responden yang memiliki status pacaran lebih banyak dari pada status menikah dan lain-lain, oleh sebab itu penelitian ini menemukan kategorisasi fungsi pacaran pada responden yang belum menikah atau pranikah. Pacaran merupakan fenomena yang cukup banyak dijumpai di zaman sekarang. Baru pada tahun 1920-an, pacaran terbentuk dan fungsi utamanya adalah untuk memilih dan mendapatkan seseorang pasangan. Sebelum periode ini, pacaran hanya bertujuan untuk menyeleksi pasangan, dan "pacaran" diawasi dengan cermat oleh orang tua, yang sepenuhnya mengendalikan kebersamaan setiap relasi heterosekual (Santrock, 2007).

Berdasarkan penelitian survei untuk mengetahui perbedaan gaya cinta mahasiswa antara laki-laki dan perempuan ditemukan adanya fungsi pacaran bagi reponden memiliki status pacaran, dimana laki-laki lebih memaknai pacaran dengan sumber kesenangan, sedangkan perempuan lebih memaknai pacaran dengan pencarian status.

Salah satu fungsi pacaran adalah sebuah bentuk rekreasi. Orang yang berpacaran akan menikmatinya dan menganggap pacaran sebagai sumber kesenangan dan rekreasi (Santrock, 2007). Penelitian ini menujukkan responden laki-laki lebih memaknai fungsi pacaran sebagai sumber kesenangan daripada perempuan, hal ini hampir sama dengan perbedaan gaya cinta sebelumnya bawasannya gaya cinta ludos (cinta main-main) memiliki prosentase lebih tinggi laki-laki daripada perempuan. Hal ini menujukkan bawasannya laki-laki lebih memaknai pacaran sebagai bentuk rekreasi dan menikmati status pacaran ini daripada perempuan.

Faktor orientasi masa depan juga berperan terhadap fungsi pacar bagi mahasiswa yang masuk pada dewasa awal sebab pada masa dewasa awal, individu memiliki harapan yang luar biasa akan masa depan sehingga individu berusaha untuk mewujudkan di kehidupan nyata dan pacar sebagai calon pendamping hidup memiliki peran terkait masa depan individu dewasa awal (Arneet, 2000). Hal ini sesuai dengan kategorisasi fungsi pacaran, bawasannya tidak hanya sumber kesenangan ternyata responden juga menujukkan kategorisasi komitmen masa depan, diketahui laki-laki memiliki prosentase lebih tinggi daripada perempuan.

Kategorsisai selanjutnya juga hampir sama yaitu ekspolorasi, dimana laki-laki memiliki kecenderungan lebih tinggi daripada perempuan. Individu yang berada pada masa dewasa awal memiliki karakteristik diantaranya terkait ekplorasi identitas (Arnett, 2000). Individu yang tergolong dewasa awal akan mengeksplorasi identitas terutama dalam hal cinta dan pekerjaan. Pada masa ini individu mengalami kemungkinan perubahan yang bersifat tidak terbatas, artinya individu dapat memilih jalan hidup secara mandiri. Salah satu kemungkinan perubahan pada individu dewasa awal adalah mencoba untuk mengesplorasi jalur karir yang ingin diambil (Arnett, 2000). Berdasarkan hal tersebut, dapat disimpulkan bahwa fungsi pacar sebagai pihak otoritas memiliki peranan penting bagi dewasa awal, seperti dalam menentukan pekerjakan maupun kota tempat bekerja.

Pada masa dewasa awal, pacaran lebih cenderung difokuskan pada couple, focused yang menekankan pada eksplorasi emosional dan keintiman fisik (Jaccard, dalam Wongso, 2014). Laki-laki memiliki kecenderungan untuk memilih perempuan berdasarkan daya tarik seksualitas sebagi suatu dasar kemenarikan seseorang untuk dijadikan pasangan hidupnya (Wongso, 2014). Selain itu laki-laki juga cenderung mencari kesesuaian dan kesegeraan berinteraksi fisik dalam hubungan. Pernyataan ini sesuai dengan hasil kategorisasi fungsi pacaran dalam penelitian ini, yakni sumber kesenangan dan eksplorasi pada laki-laki lebih tinggi daripada perempuan. Sedangkan orientasi untuk masa depan atau komitmen pada masa depan terhadap pacar sebagai calon pendamping juga memiliki peran masa depan untuk dewasa awal itu sendiri, sehingga individu dapat berusaha mewujudkan kehidupan nyata. Fungsi pacar terakhir adalah mencari status, pacaran dapat menjadi sumber yang meberikan status dan prestasi. Dalam kategorisasi mencari status, perempuan memiliki jumlah yang lebih tinggi daripada perempuan. Hal ini menujukkan bawasannya perempuan lebih cenderung mengartikan status pacaran sebagai pencarian dan memberikan status semata dibandingkan laki-laki.

Masa dewasa awal adalah masa pencarian kemantapan dan masa reproduktif, yaitu suatu 
masa yang penuh dengan masalah dan ketegangan emosional, periode isolasi sosial, periode komitmen dan masa ketergantungan, perubahan nilai-nilai, kreatifitas, dan penyesuaian diri pada pola hidup yang baru (Dariyo, 2003). Pada tahap perkembangan dewasa awal, individu akan mengalami perubahan signifikan dalam hubungan personal dengan orang lain, terutama yang berkaitan dengan menjalin dan membangun ikatan berdasarkan pertemanan, cinta, dan seksualita (Papalia, 2008). Kehidupan psikososial dewasa awal semakin kompleks diandingkan masa remaja khusunya yang memilih untuk melanjutkan jenjang ke perguruan tinggi. Pemilihan dan menemukan calon pasangan hidup adalah salah satu tugas perkembangan pada dewasa awal. Pemilihan akan menikah ataupun hanya sekedar hubungan pranikah atau biasanya disebut pacaran atau yang lainnya adalah wajar bagi dewasa awal karena mengingat tugas perkembangan tersebut (Hurlock, 1980).

Pemilihan pasangan perempuan maupun laki-laki memiliki daya tarik tersendiri dalam memutuskan pasangan sehingga menjalin sebuah hubungan yang didasari akan cinta. Daya tarik fisik merupakan hal yang penting bagi seseorang untuk menentukan pasangan hidupnya. Akan tetapi ternyata daya tarik psikis atau pribadi adalah penilaian utama sebelum memutuskan mencintai. Seperti dalam penelian Faturochman (1988) yang meneliti mengenai daya tarik fisik laki-laki dan perempuan, ditemukan kedua kelompok yakni lakilaki dan perempuan lebih mengutamakan faktor psikis seperti nilai-nilai, kepribadian, kecerdasan, prestasi, dan keberhasilan daripada faktor yang bersifat fisik seperti ketampanan atau kecantikan dan kedekatan fisik. Selain ketertarikan pribadi dan fisik, seseorang juga cenderung memiliki pasangan yang memiliki kedekatan atau keakraban dan kesamaan atau kemiripan.

Daya tarik inilah yang akan menimbulkan sebuah hubungan yang dilandasakan akan cinta. Berkenaan dengan cinta, Kienlen (2007) menyebutkan tiga tahapan dalam percintaan, yaitu romantic feeling (rasa cinta), ketertarikan fisik, dan kelekatan emosi. Pertama-tama perasaan cinta muncul pada individu karena adanya kedekatan dengan lawan- jenis. Selanjutnya, pikiran individu dipenuhi oleh orang terkasih dan mulai menjadikan sebagai pasangan yang ideal. Tahap ketertarikan fisik ini sering dikatakan sebagai fase "lovesick" atau mabuk kepayang. Kemudian hubungan berlanjut pada kelekatan emosi yang melibatkan komitmen, pertemanan, atau bahkan anak. Pada tahap terakhir individu mengetahui karakter positif maupun negatif dari pasangan, dan memutuskan apakah ingin membangun kehidupan bersama, ketiga tahapan ini tidak saling terpisah melainkan perpaduan ketiganya dalam hubungan romantis jangka panjang, salah satunya adalah ikatan pernikahan dengan komitmen untuk saling berbagi (Stuzer \& Frey, 2006).

Hubungan yang berdasarkan cinta dapat memunculkan berbagai tipe atau gaya cinta, dimana John Lee mengungkapkan terdapat 6 gaya cinta yakni meliputi eros (gaya cinta romantis), ludos (permainan cinta), dan strong (cinta persabatan), mania (cinta posesif), pragma (Realistis cinta), dan agape (cinta tanpa pamrih). Akan tetapi John Lee, yang mengungkapakan bahwa jarang individu yang mempunyai bentuk cinta "murni" karena pada umumnya individu memiliki dua atau tiga bentuk gaya cinta yang dominan (Taylor, 2009).

Untuk penelitian yang akan datang, hendaknya peneliti menggali lagi mengenai sejumlah faktor yang mungkin saling terkait satu sama lain terhadap gaya cinta, sehingga hasil yang diperoleh dapat lebih dimaksimalkan. Adapun kekurangan dan keterbatasan dalam penelitian ini adalah masih belum maksimalnya responden dari berbagai status pacaran, menikah maupun lain-lain. Sehingga masih belum bisa mewakili keseluruan populasi. Selain itu, skala dalam penelitian ini memiliki item gugur yang cukup banyak sehingga sedikit mempengaruhi pengolahan maupun analisa data. Keterbatasan penelitian ini diharapkan dapat dijadikan pertimbangan lebih lanjut bagi peneliti selanjutnya.

\section{PENUTUP \\ Kesimpulan}

Berdasarkan hasil dari analisa data dan pembahasan atas hasil penelitian, maka dapat disimpulkan sebagai berikut: 1). Gaya cinta yang dimiliki mahasiswa menujukkan kebanyakan dua atau lebih gaya cinta yang dominan dalam dirinya, akan tetapi terdapat pula gaya cinta murni pada enam gaya cinta yakni eros (cinta romantik), ludos (cinta main-main), storge (cinta kawan baik), mania (cinta posesif), pragma (cinta realitas), dan agape (cinta tanpa pamrih). Kombinasi gaya cinta mahasiswa yang paling tinggi ditunjukkan pada kombinasi gaya cinta storge-pragma yaitu cinta kawan baik dan cinta realistis.2) Perbedaan gaya cinta yang dimiliki pada mahasiswa menujukkan terdapat perbedaan pada gaya cinta ludos (cinta 
main-main) dan agape (cinta tanpa pamrih) antara laki-laki dan perempuan sedangkan, dimana lakilaki lebih dominan dibandingkan perempuan. Hal ini ditunjukkan dengan jumlah responden laki-laki lebih dominan kepada gaya tersebut daripada perempuan. Sedangkan gaya cinta eros (cinta romantik), storge (cinta kawan baik), mania (cinta posesif), dan pragma (cinta realitas) tidak memiliki perbedaan antara laki-laki dan perempuan.

\section{Saran}

Berdasarkan hasil penelitian dan pembahasan, dapat menjadi kajian terhadap mahasiswa dewasa awal mengenai pentingnya mengetahui gaya cinta mahasiswa dalam tugas perkembanganya,

\section{DAFTAR PUSTAKA}

Anshori, M \& Iswati, S. (2009). Metode Penelitian Kuantitatif. Surabaya: Airlangga University Press

Arnett, J.J. (2000). Emerging adulthood. A theory of development from the late teens through the twenties. American Psychologist. Vol. 55 No.5, 467-480

Baron, R. A\& Byrne, D. (2004). Psikologi Sosial jilid 1 Edisi Sepeluh. Jakarta: Penerbit Erlangga

Cannary, D.J, Faulkner, S\& Emmers-Sommer, T.M. (1997). Sex and gender differences in personal relationship. New York: The Guilford Press

Creswell, JW. (2010). Research Design (Pendekatan Kualitatif, Kuantitatif, dan Mixed). Yogyakarta: Pustaka Pelajar

Dariyo, A. (2003). Psikologi Perkembangan Dewasa Awal. Jakarta: Gasindo

Dayakisni, T \& Hudaniah.( 2009). Psikologi sosial. Malang: UMM Press.

Faturochman. (1988). Studi tentang daya tarik fisik laki-laki dan perempuan. Laporan Penelitian

Faturochman. (2006). Pengantar Psikologi Sosial. Yogyakarta: Penerbit Pustaka

Fitriani, R. (2014). Gaya cinta remaja akhir. Jurnal Online Psikologi Universitas Muhammadiyah Malang. Vol 02, No 01, 1-16

Freud, S. (2009). Terjemahan: Pengantar Umum Psikoanalisis (A General Introduction to Psycholoanalysis). Yogyakarta: Pustaka Pelajarar dan dapat pula sebagai bahan kajian pembinaan kemahasiwaan yaitu dalam mengenalkan mahasiswa baru untuk menjalin hubungan cinta dengan gaya cinta yang ada sesuai nilai-nilai yang positif dan kaidah agama..

Bagi penelitian selanjutnya, hendaknya peneliti menggali lagi mengenai sejumlah faktor yang mungkin saling terkait satu sama lain terhadap gaya cinta, seperti pengalaman, pola asuh, lingkungan, budaya, dan lain sebagianya, sehingga hasil yang diperoleh dapat lebih dimaksimalkan. Serta dapat mengumpulkan data yang lebih bervariasi lagi, seperti rentang dewasa awal dengan cara memberikan kuota partisipan untuk setiap usia.

Freud, S. (2010). Terjemahan: Deviant Love (Cinta yang Menyimpang). Surabaya: PORTICO publishing

Fromm, E. (2005). The Art Of Loving. Jakarta: Gramedia Pustaka Utama

Gonzaga, GC, Londahl, EA, \& Smith, MD. (2001). Love and the commitment problem inromantic relations and friendship. Journal of Personality and Social Psychology. Vol. 81, No 2, 247262

Hendrick, S.S \& Hendrick, C. (1986). A theory and method of love. Journal of Personality and Social Psychology. 50: 392-402

Hurlock, EB. (1980). Psikologi Perkembangan (Suatu Pendekatan Sepanjang Rentang Kehidupan) Edisi Kelima. Jakarta: Penerbit Erlangga

Irmawati dan Saragih J.I. (2005). Fenomena jatuh cinta pada mahasiswa. Jurnal Psikologi Fakultas Kedokteran Universitas Sumatera Utara. Vol. 1, No. 1, 48-55

Keinlen, L.P. (2007). "3 Stages of Love: Romantic Feelings, Physical Attraction, and Emotional Attachment". http://perasaancinta-capung. blogspot.co.id/2011/06/3-stages-of-love-inrelationships.html. (diakses tanggal 8 Maret 2016)

Marasabessy, R. (2007). Perbedaan cinta berdasarkan teori segitiga cinta Sternberg antara perempuan dengan laki-laki masa dewasa awal. Jurnal Universitas Gunadarma

Mendatu, A. (2010). Cinta Manusia (Arti, ragam jenis, dan sebab akibatnya). Psikoedukasi:https:// 
aseranikurdi.files.wordpress.com/2011/09/ cintamanusia. (diakses tanggal 8 Nopember 2015)

Meneg PP. (2012). Meneg PP: Satu dari lima remaja alami pelecehan seksual (artikel). Harian umum Pelita: http://www.pelita.or.id/baca. php?id=47477. (diakses tanggal 2 September 2015)

Myers, D.G. (2012). Psikologi Sosial: Buku 2. Jakarta: Salemba Humanika

Papalia, D, Old SW, Feldman RD. (2008). Human Development: Psikologi Perkembangan. Jakarta: Kencana Prenada Media Grup

Pease, B \& Allan. (2009). Terjemahan: Why men don't listen and women can't read map. Jakarta: Cahaya Insan Suci

Prasetyo, B \& Jannah, LM. (2012). Metode Penelitian Kuantitatif. Jakarta: Rajawali Pers

Santrock, John W. (2002). Life Span Development. Jakarta: Penerbit Erlangga

Santrock, John W. (2007). Remaja edisi sebelas jilid dua. Jakarta: Penerbit Erlangga

Santrock, John W. (2012). Life Span Development. Jakarta: Penerbit Erlangga

Saragih, J.I. (2006). Bentuk-bentuk cinta berdasarkan tringular theory of love. www.repository.usu. ac.id . (diakses tanggal 7 Maret 2016)

Sarwono, S\& Meinarno, EA. (2009). Psikologi Sosial. Jakarta: Salemba Humanika
Sears, D. O, Freedman, J.L, \& Peplau, L.A. (1994). Psikologi Sosisal. Edisi 5. Jakarta Erlangga.

Setyorini, E.W. (2007). Perbedaan gaya cinta pada remaja akhir ditinjau dari peran gender Jurnal Universitas Muhammadiyah Malang. www.digilib.umm.ac.id. (diakses tanggal 9 Oktober 2015)

Sholihah, N. (2006). Gender dan Jenis Kelamin. http:// pmiiliga.wodpress.com. (diakses tanggal 2 Sepetember 2015)

Sobur, A. (2003). Psikologi Umum dalam Lintas Sejarah. Bandung: Pustaka Setia

Stuzer, A \& Frey, B.S. (2006). Does marriage make people happy, or do happy people get married?. The Journal of Socio-Economics. Vol. 35, 326-347

Sugiyono. (2012). Metode Penelitian Kuantitatif Kualitatif dan $R$ \& $D$. Bandung : Alfabeta

Taylor, Shelley E, Sears, D.O dan Peplau. L.A. (2009). Psikologi sosial edisi kedua belas. Jakarta: Kencana Perdana Media Group

Todosijevic B,. Arancic A, \& \& Ljubinkovic. (2009). An Examanation and Revision of the Love Attitude Scale in Serbia. University of Novi Sad, Serbia.

Wisnuwardani, D\& Mashoedi, S F. (2012). Hubungan Interpersonal. Jakarta: Salemba Humanika

Wongso, F. (2014). Peran Pacar bagi Emerging Adulthood Laki-laki. Jurnal Ilmiah Mahasiswa Universitas Surabaya. Vol. 3, No. 1, 1-14 